\title{
Railroad Interests in Early Iowa
}

Leonard F. Ralston

A FREQUENTLY USED pontrait of large economic interests in the United States conforms to that drawn in the early Twentieth Century from a progressive view of reality. ${ }^{1}$ To the progressive reformer, the lobbyist and his employers were arrogant,' contemptuous of contemporary morality, and worked their dishonest and devious wills in underhanded ways, including the seduction of elected representatives by lavish distribution of bribes. Their schemes were invariably contrary to the public welfare and destructive of the cherished rights of the common man. The portrait was limned in deepest black and lurid purple.

The purpose of this essay is to put the much maligned railroad leaders into the perspective of the times and issues which confronted citizens and railroad leaders alike. The 1850s and 1860s in Iowa were times of new developments and new problems, both for the railroads and for the government officials responsible to the public. The activities of the railroaders can be seen not only as the efforts to serve their own interests, but as efforts to serve a larger, though more vaguely defined public interest in the context of a healthy respect for the state's government.

Between 1850 and 1870, Iowa was still in the frontier stage of development. Even as pioneers attacked the tough sod of the central Iowa prairies, eastern Iowans turned to the development of railroads to give themselves a more efficient transportation system. The Mississippi Riyer proved useful only to those on its banks and attempts during the $1840 \mathrm{~s}$ to

${ }^{1}$ See Lee Benson's discussion in Turner and Beard (New York, $1960)$ pp. 103-106. 
improve navigation on the Des Moines River were ultimately of little use. ${ }^{2}$ When they failed to find the necessary interior transportation by water, residents of the state gave their enthusiastic support to the construction of railroads, the transportation panacea of the $1850 \mathrm{~s}$. The earliest railroad projects were essentially local enterprises intended to link the budding Mississippi River cities of Dubuque, Clinton, Davenport, Burlington and Keokuk with the interior, despite grand titles, such as "The Dubuque and Pacific." The early roads also sought connection with eastern markets, and, by 1870 all had become parts of larger systems radiating out of Chicago: the Illinois Central; the Chicago Northwestern; the Chicago, Rock Island, and Pacific; and the Chicago, Burlington, and Quincy.

Supporters of these early east-west lines sought and found a major source of financial support in the multiple land grants given by the federal government in 1856. Four lines were projected and supported with grants, although the lands were actually given to the State of Iowa, to be tendered to the railroads as construction progressed. A spirited contest between the state and the railroads followed as the railroads sought quick title to their lands, while the state acted to withhold the lands as long as possible to compel the railroads to complete the promised lines. Although land grants were squandered in some states, such was certainly not the case in Iowa. ${ }^{3}$

In addition to the contest over construction deadlines and land title, the complex development of frontier Iowa combined with the still more complex growth of the railroads to produce a myriad of problems and projected solutions. Three roughly discernable stages passed across the state in accompaniment to the spread of the railroads. Before any track was laid in Iowa, the early settlers eagerly anticipated the prosperity which they were certain would come with easy access to eastern markets. Boosters proved their enthusiasm by offering all sorts of material and moral support of railroads.

${ }^{2}$ Jacob A. Swisher, "The Des Moines River Improvement Project," Iowa Journal of History and Politics, XXXV (April, 1937) $142 \mathrm{ff}$.

${ }^{3}$ Leonard F. Ralston, "Railroads and the Government of Iowa, 1850-1872 (Unpublished Ph.D. Dissertation, University of Iowa, 1960). 
After the railroads had arrived in eastern Iowa, the long awaited connection with the outside world proved as disturbing as it was rewarding. Sentiment favoring control of the railroads grew in this environment. The greatest concerns of these early critics were high rates, property destruction, and the adequate taxation of railroad property.

Even as railroad-less boosters in western Iowa urged faster construction, disillusioned initiates in central Iowa called for the same controls and responsibilities as eastern Iowans had demanded a few years earlier. At the same time, yet a third stage was emerging in the eastern portion of the state. Residents of this "old" region had long since passed through the reckless and enthusiastic "railroads at any cost" stage, had weathered the confusion of change that more direct contact with outside markets brought, and were now finding a permanent, lasting adjustment to the new world. Thus, by the end of the period under consideration, eastern Iowans found less reason to support the controls and limitations demanded by those still seeking ways to live with the railroads. ${ }^{4}$

At the same time that people in the different regions of the state were in such conflicting stages of change and adaptation to the new order, the railroads themselves underwent rapid change. They moved rapidly from local enterprises concerned only with restricted areas and became parts of larger, interstate systems as railroad managers sought the advantages provided by more adequate capitalization, better connections, and the manifold economies of large scale operation. Within this complex of change and adjustment, railroad managers and their representatives at the state capitol in Des Moines sought to resolve conflict, assure confidence in the future, and preserve the interests of the railroads. While the circumstances provided an obvious conditioning factor, the attitudes and beliefs of the railroad men also influenced their activities and their decision-making.

The attitudes of the railroad men toward railroads, whether a rationalization of self interest or a sincere belief, provided part of the framework within which they worked. One basic assumption railroad men made to justify their course of

${ }^{4}$ Ibid. 
action was the claim that railroads had prime value and importance for the development of the state. Railroads, said one, did more "to develop the resources of the [state], to induce emigration, enhance the value of lands in the interior and thus increase the revenue of the state than any other agency." Farmers, said another, "require cheap transportation-without railroads in many portions of [the state] they can have no transportation . . . \& consequently no markets."

The negative statement of the same idea was even more common. "We think we are entitled to a liberal policy on the part of state authorities. At all events they cannot kill us without committing suicide at the same time," said John A. Dix of the Mississippi and Missouri (later to become the Chicago, Rock Island, and Pacific). ${ }^{7}$ Henry Farnam of the same road berated the legislature which had made extreme charges against the railroads, "not dreaming for a moment that their own lifeblood (the commonwealth) is drawn and receives its sustenance from its [the railroads] influence."

Another form of this negative argument stressed the danger that railroad building would cease in Iowa if unwise legislation frightened eastern capitalists. Charles Perkins of the Chicago, Burlington, and Quincy argued that "people that in these days \& in a new country like this, do not see the necessity of encouraging Eastern Capital . . . should not be voted for to make our laws-Iowa is making a reputation for antiRailroad legislation wh[ich] will materially retard her growth." John Dix wrote that delaying transfer of land titles to the M. \& M. could not prevent the road from ultimately gaining the lands, "but it would have the most un-

${ }^{5}$ Edward Kilbourne to David W. Kilbourne, February 8, 1864, David W. Kilbourne Papers (Iowa State Department of History and Archives, Des Moines), Vol. 10. Hereafter cited as DWK.

${ }^{6}$ D. W. Kilbourne to Editor, Des Moines Daily State Register, February 4, 1868, DWK, Letter Press Books.

${ }^{7}$ John A. Dix to Peter A. Dey, February 4, 1860, Grenville M. Dodge Papers, Vol. I (Iowa State Department of History and Archives, Des Moines) Hereafter cited as GMD. Vol. 150.

${ }^{8}$ Henry Farnam to Grenville M. Dodge, March 4, 1860, GMD,

${ }^{9}$ Charles E. Perkins to Wilson, March 19, 1864, CunninghamOverton Collection, Letter Press Book "C" (Newberry Library, Chicago). Hereafter cited as $C O$. 
fortunate influence on the new impulse recently given to the work by impairing the confidence of Capitalists, who are always timid \& making it impossible to sell our bonds."10 All this would eventually damage the state, for it would hinder or prevent the further construction of railroads, which, it logically followed, were in the best interests of the state.

A subtler form of self-esteem is revealed in a simple content analysis of the correspondence of the railroad men. Most of the twenty-three men whose letters were used in this study consistently capitalized such words as "Railroad" or "Road" or "Company," whether used in the generic or personal sense. Of the two who did not, only one always used lower case letters and his letters were always written by a secretary. ${ }^{11}$

The railroad men also consistently claimed that railroad investments were unprofitable, thereby showing another variety of public spirit. "It is a well known fact," wrote one, "that builders of railroads, throughout our country, have as a rule, been losers by their enterprize." He claimed that the earnings of his railroad were insufficient to pay the interest on the bonded debt, with no hope of returning anything to the stockholders. ${ }^{12}$ Others echoed the same sentiments. "I think sometimes I am a great fool for sending one dollar of good money after bad \& making myself so anxious about Rail Rs matters in Iowa-for I do not see the least chance of geting [sic] my money back again under any Circumstances," wrote Henry Farnam. ${ }^{13}$ Another blamed himself for having involved

${ }^{10}$ Dix to Dey, February 4, 1860, GMD, Vol. 1.

${ }^{1}$ The letters used in this study were written by John N. Denison, Charles A. Perkins, and Joshua Tracy of the Chicago, Burlington \& Quincy; Caleb Baldwin, Peter A. Dey, John A. Dix, Grenville M. Dodge, Henry Farnam, H. M. Hoxie, and Hiram Price of the Mississippi and Missouri-Chicago, Rock Island and Pacific; L. B. Crocker and John A. Kasson of the Cedar Rapids and Missouri River (later the Chicago Northwestern); John I. Blair, J. P. Farley, William W. Hainilton, James McKinlay, C. H. Perry, and Platt Smith of the Dubuque and Pacific-Dubuque and Sioux City-Iowa Falls and Sioux CityIllinois Central; David W. Kilbourne, William Leighton, and Hugh T. Reid of the Keokuk, Fort Des Moines and Minnesota-Des Moines Valley. Only Platt Smith's letters consistently used lower case letters.

${ }^{12}$ John N. Denison to Governor William Stone, February 7, 1864, Covernor's Correspondence, C. II, File 626 (Iowa State Department of History and Archives, Des Moines) Hereafter cited as G II.

${ }^{13}$ Henry Farnam to Dodge, March 17, 1860, GMD, Vol. 1. 
his friends in such an unprofitable and money-losing venture. ${ }^{14}$

Obviously the level of activity in railroad building casts doubt on these doleful assessments. However, it was true that among the alternative uses for capital at that time, western railroads, built for the most part ahead of traffic, were attractive only in special circumstances and with extra incentives. The marginal prospect for equitable profit quite naturally led railroad men to take pessimistic views.

Since railroads were considered unpromising, the only basis on which capitalists could be induced to venture their funds was on the promise of future gains, or side profits. To convince investors that these were possible, the railroad men insisted it was necessary to avoid antagonistic legislation. Perkins of the C.B. \& Q. admitted that railroads were built for profit, but added that, unlike other businesses, they required such large amounts of capital that any state actions which frightened prospective investors endangered the enterprise in a way that injured no other business in the state. ${ }^{15}$

Although common among legislators who supported the railroads, the infant industry theme implied in the demand for special consideration did not have much currency among the railroad men. The phrase was used only once in all the correspondence studied. In fact, John Denison of the C.B. \& Q. went to the opposite extreme when he likened railroads to "prematurely old spavined \& broken down nags" who needed to be cared for and aided to their feet, rather than "wild young colts" which the legislature seemed to think needed breaking and fettering. ${ }^{16}$ Whatever use the railroad men made of the argument was phrased in terms of the interests of the state, not the infancy of the railroads.

Another set of attitudes which influenced the railroad men was that toward other railroads. The railroad men had a curiously uneven regard for their competitors. Concerning land grant matters, they often suspected each other's motives and preferred to go alone in the pursuit of their lands. When

${ }^{14}$ Denison to J. G. Foote, February 12, 1862, Chicago, Burlington, and Quincy Archives, 5 D4.1 (Newberry Library, Chicago) Hereafter cited as $C B Q$.

${ }^{15}$ Perkins to Joshua Tracy, February 6, 1866, CO, LPB "E".

${ }^{16}$ Denison to Foote, March 5, 1864, CBQ, 5 D4.1. 
a new company asked for the land grant of one of the original grantee companies which had failed to build its line, the other railroads remained aloof. Directors of one road feared that a new company intended changing its route to closely parallel and compete with its own. To a centain extent the other roads considered the new company an usurper who would have pounced on their lands under different circumstances. $^{17}$

On another occasion, in the midst of an intricate and intolerably confused struggle over conflicting land claims, the men of the Des Moines Valley Railroad preferred to stay out. Some of the contested lands would accrue to the D.M.V., and, in addition, the interested roads had tried to prevent the D.M.V. from obtaining a transfer of the river improvement grant to build its railroad. ${ }^{18}$

When legislation pended to revoke and regrant all of the land grants so that the legislature could insert a clause giving the state clear power to regulate rates, there was generally no planned cooperation among the railroads to prevent this action, even though there was considerable opposition to the offending clause. In a few specific instances, however, railroad men worked together for common purposes. Certain common problems, such as failure to meet legislative deadlines and swamp land claims called for cooperation. In the summer of 1865 , "a railroad convention was held . . . by some of the Iowa roads with a view to consulting as to what legislation was necessary," reported one railroad man. ${ }^{19}$ The results were not reported.

For the most part, the railroad representatives in Des

${ }^{17}$ The 'Iowa Central Airline Railroad, grantee for the road west from the vicinity of Clinton, built only as far west as Cedar Rapids. A new company, under the driving leadership of New Jerseyite John I. Blair sought and obtained transfer of the land grant. The Rock Island leaders were suspicious of Blair and disliked the idea of resumption and regrant of the land grant under any circumstances. Ralston, "Railroads and the Government of Iowa," pp. 64-65.

${ }^{18}$ Leonard F. Ralston, "Iowa Railroads and the Des Moines River Improvement Land Grant of 1846," Iowa Journal of History, LVI (April, 1958) pp. $97 \mathrm{ff}$.

${ }^{19}$ Platt Smith to Morris K. Jesup, January 17, 1866, Illinois Central Archives, 8 D8.16 (Newberry Library, Chicago) Hereafter cited as $I C$. 
Moines preferred to work independently. Usually they knew of the presence of other railroad men and occasionally mentioned them by name, but rarely gave them any credit for accomplishments. Sometimes it was "we," but more frequently, the lobbyist used the first person singular.

The railroaders' attitudes toward state government were ambivalent. In general, they regarded the government as an obstacle to be overcome if the railroads were to prosper. All railroad men naturally believed that railroads were good for the state and its people, as the carriers of progress and prosperity. Since railroads had such great value for the state, and the state would be the great loser from restrictive legislation, it frequently followed that the only reasonable explanations for restriction had to be the hostility, malice, ignorance, cupidity, or downright stupidity of the individual legislators. Within this conceptual framework, the railroad men could not accede graciously to the idea that regulation was necessary or justified.

There were some exceptions to this view of the state as an antagonist. When railroad construction stalled after the panic of 1857, some of the railroad men turned unsuccessfully to the state to find additional capital. Later, when it seemed certain that the prevailing tax on the gross receipts of the companies had to be abandoned as unconstitutional, most railroad men turned quickly to the state to save them from the extortions of local assessors. They had more confidence in the restraint of the state.

Most often, railroad attitudes were shaped by the desire to avoid legislation which would interrupt the flow of new capital or subject the railroads to arbitrary controls. Taxation was expected and accommodated as a predictable expense, even if the cost was resented, but the capricious behavior of local assessors and tax collectors was not to be borne. Similar$\mathrm{ly}$, the exercise of the state's police power in regulating rates was considered undesirable, especially when enacted by such an unpredictable and changeable body as the general assembly. When regulation became an unavoidable fact, the railroads much preferred a commission as a regulatory body, for it was more independent of popular will and more enduring- 
qualities which made it possible to adjust to it and plan around it

Since the constitution and laws of Iowa limited and circumscribed the governors' powers more than those of the legislature, one might expect that the governors would have been less feared than the legislators. In most instances, this was true. The only real power over the railroads held by the governor was his duty to certify lands as the railroads completed statutory construction requirements. However, in most instances, legislative proscriptions limited the governor's discretion. Few of the governors had the strength or will to confront the legislature head on. In addition, most of the govemors were favorably disposed toward the railroads.

Nonetheless, the railroad men tended to assume that the governor possessed more power than was the case. Throughout the difficult period when the railroads fell further and further behind construction requirements and into financial difficulties, the railroaders exerted pressure on the governor to pass over title to the lands the railroads had already earned. After one early governor's indiscretion cost the state its power to coerce one railroad, the legislature took the reins. From that time, the governors consistently refused to give title to lands without legislative approval. The Iowa courts backed the governors and ruled that the railroads were not entitled to the lands until they had met all legislative requirements. Although some railroaders castigated the governors, in most cases they realized that the real culprit was the legislature and directed their fire in that direction. ${ }^{20}$

The railroad men frequently called on the governor as an ally. After the panic of 1857, Platt Smith of the Dubuque and Pacific initiated a move for state aid. Govemor Ralph P. Lowe accepted the call and became the only Iowa governor to actively support state aid for the railroads. But Lowe was not strong enough to carry the movement to success. Both the spector of state bankruptcy, inherited from the internal improvement schemes of Illinois and Indiana two decades earlier, and the opposition of his own Republican party, killed the project. Lowe was denied a second term as governor, partly

${ }^{20}$ Ralston, "Railroads and the Covernment of Iowa," pp. 51-54. 
as a punishment for his indiscretion. ${ }^{21}$

Later Smith tried to convince Governor William Stone that it was his duty to issue land certificates to his railroad. He claimed that the act of Congress bestowing the lands on the railroads with limited stipulations was superior to any act of the Iowa legislature which insisted on added conditions. "Where Congress requires the governor to certify to certain facts, I do not believe that the legislature had any authority to require the governor to withhold his certificate when he knows that the facts really exist," he said. ${ }^{22}$ In spite of Smith's blandishments, Stone remained true to the demands of the legislature.

However unrewarding this faith in the governor proved to be in fact, the railroad men acted as though it was necessary. The governors usually received passes from the various roads, and railroad leaders even issued passes to others at the request of the governors. On one notable occasion, the railroads acquiesced reluctantly in one governor's grand scheme to transport all Iowa veterans of the Union army to a reunion in Des Moines during the summer of 1870. An estimated 30,000 veterans used the railroads' largesse to attend. While this undoubtedly represented a gesture of good will toward a group with great political potential, it also represented an assumption that the good will of the governor was important. ${ }^{23}$ Although currying gubernatorial favor never resulted in any positive action contrary to the wishes of the legislature, it is also true that most governors remained favorably disposed toward the railroads. Insofar as the governors did not take the lead in proposing anti-railroad legislation, the railroad strategy succeeded.

Railroad men more consistently looked to the general

${ }^{2}$ Leonard F. Ralston, "Governor Ralph P. Lowe and State Aid to Railroads: Iowa Politics in 1859," Iowa Journal of History, LVI (July,
1960 ) pp. $207 \mathrm{ff}$.

${ }^{22}$ Smith to Stone, March 8, 1864, IC, 8 D8.16.

${ }^{23} \mathrm{On}$ May 24,1870 , Governor Samuel Merrill received a letter from Perkins of the $C B \& Q$ refusing to give passes, to which Merrill replied that he had agreement from the CRI \& $\mathrm{P}$, the CNW, the CM \& St. P. the IC, and the DMV. On July 1st, Perkins apparently changed his mind and cooperated. Merrill not only gained free transportation from the railroads, but also free use of telegraph lines. Merrill to Perkins, May 24, 1870, July 5, 1870, G II, Vol. II, pp. 18, 22. 
assembly, rather than to the governor or the judiciary as the primary source of both boon and burden. Those who concerned themselves with the legislature frequently expressed themselves on the subject, rarely in complimentary terms. Grenville M. Dodge claimed that the 1857 House had "not one smart man in it." A basis for that judgment might have been his inability to move it, for, as he confessed, "we could do but little with it as it had no head or tail to it." ${ }^{\prime 24}$ In 1864, David W. Kilbourne of the D.M.V. claimed that the legislature "talked more \& [did] less" than any other. He complained that too many ministers and lawyers wasted the assembly's time in oratory. The addition of "a good many farmers" who feared monopolies, as they called the railroads, did not improve the body. Kilbourne fretted because legislation affecting his land grant gathered dust while the orators performed. ${ }^{25}$ The 1866 legislature, according to Hugh Reid of the D.M.V., was "a more intelligent one than we have had for some time," but very radical, introducing "all kinds of abominable antiRail Road Bills." Reid had difficulty leading the same "intelligent" legislature down the proper path and began to question the wisdom of the members. In great exasperation, he finally declared that they had become so confused by excessive legislation about the D.M.V. land grant that it was "out of the question to beat it into the heads of the members" that their approach to the problem was wrong. ${ }^{26}$ A distressed Kilbourne declared two years later that he "would rather trust copperheads to do justice ... than the radical-contracted republican souls of the Iowa Legislature." ${ }^{\text {27 }}$ Charles Perkins thought too many dishonest men got into the legislature and too many "who understand very little about what the real prosperity of their constituents depends upon." ${ }^{28}$

Though the disparaging attitude often prevailed, the remark by Perkins represents a much commoner conception of the legislators' faults. According to this view, the solons either

${ }^{24}$ Dodge to Caleb Baldwin, January 29, 185[7], GMD, Vol. 1. Vol. 10 .

${ }^{25} \mathrm{D}$. W. Kilbourne to William Leighton, February 29, 1864, DWK,

"HiHugh Reid to D. W. Kilbourne, February 2, March 15, 1866, DWK, Vol. 13 .

${ }^{27} \mathrm{D}$. W. Kilbourne to Reid, March 20, 1868, DWK, LPB.

${ }^{28}$ Perkins to G. W. Beymer, June 22, 1868, CO, LPB "F." 
did not understand what their true interests were, or were mislead by stronger wills. John Denison of the C.B. \& Q. attempted to convince Senator John G. Foote of Burlington that the tax policy he advocated was foolish. Denison bombarded Foote with arguments to show that the interests of Burlington and the state depended on a sane mode of taxation. Denison exclaimed, "I wish that you and I could change places for one week. Not that I regard myself as better fitted for your place than you are but that you might be enlightened in regard to the difficulties of mine." Denison insisted that Foote was misinformed about the true nature of railroads. ${ }^{29}$ Platt Smith wrote the Senator from Dubuque that the legislature "didn't understand the effect of the act [concerning the Des Moines River lands] at the time it was passed and don't understand it now." Somewhat immodestly, he added, "I understand it perfectly.",

Increasingly as time passed, the railroads regarded the legislature as hostile or antagonistic. The intensity of this attitude increased in direct proportion to the state's exercise of regulatory and police powers. When an act "defining duties of Rail Road Companies" in 1860 proposed to make the railroads build fences along their rights of way or pay damages for animals killed, Farnam regarded this' as hostile legislation and wondered why the legislature did not take some common sense view. "But they seem to think that a Rail Road Compy [sic] is some terrible monster to be caught, chained and rob [b]ed \& then bled to death." ${ }^{31}$ After summarizing the proposed legislation of one session, Reid of the D.M.V. almost invariably commented in the same vein: "The present legislature is not very favorable disposed toward Rail Roads" or, "The disposition of the House of Representatives is decidedly hostile to Rail Roads" or, "There is an inte[n] sly hostile feeling in the House against Rail Roads." ${ }^{\text {32 }}$ Charles Perkins asked Fitz Henry Warren in 1861 if there was going to be an "Effort to

${ }^{20}$ Denison to Foote, February 11, 12, 1862, February 1, March 5, 12, 1864, CBQ, 5 D4.1.

${ }^{30}$ Smith to B. B. Richards, February $7,1866, I C, 8$ D8.16.

${ }^{31}$ Farnam to Dodge, March 4, 1860, GMD, Vol. 150.

${ }^{32}$ Reid to D. W. Kilbourne, February 7, 1860, DWK, Vol. 7; March 6, 15, 1866, DWK, Vol. 13. 
damn the railroads this winter?" and later, "If the convention' of Doctors which is to assembly or has assembled at Des Moines this winter does not decide upon too profuse a bleeding of Railroads I hope our people may be induced to push on for the Pacific connection next year."':3 Platt Smith commented sadly, "I am sorry there is so much apparent indiference [sic] and hostility to railroads in the legislature." Kilbourne righteously expostulated, "The course of the Iowa Legislature is perfectly abominable in regard to Railroads." ${ }^{\text {3. }}$

The railroad men seldom tried to analyze the source of this "hostility." It was apparently satisfactory to attribute it to personal injury, lack of intelligence, or the generally perverse nature of mankind. Or perhaps it stemmed from the emerging managerial requirements of large industry. The combination of heavy capital requirements and delayed or deferred profits made predictable government policy essential. As Louis Hartz said in his analysis of Pennsylvania economic development, business welfare demanded long-term planning and opposing change. What the railroads wanted was an "increasingly stable legal and political environment"3is at the same time that the government of the state, through the legislature, was trying to define a place for the railroads in the state's economic structure. Railroad resistance to outside change combined with a public imperative to accommodate through change to new conditions made conflict inevitable.

The need to control or direct legislative aberrations soon called forth the lobby. Not notably present in the earliest years, the railroad men gradually took up the job of influencing the legislators as the stakes became greater. They wrote letters, as Denison did to Foote. They attended the sessions of the legislature, waited upon members in the lobbies, spoke with them in chambers during the day and instructed them in railroad quarters during the evenings. When committees considered legislation affecting the railroads, they appeared as

${ }^{33}$ Perkins to Fitz Henry Warren, January 8, 1864, CO, LPB "D"; January 8, 1868, CO, LPB “F."

${ }^{34}$ Smith to George W. Bassett, March 3, 1864, IC, 8 D8.16.

${ }^{35} \mathrm{D}$. W. Kilbourne to Reid, March 20, 1868, DWK, LPB.

${ }^{36}$ Louis Hartz, Economic Policy and Democratic Thought (Cambridge, 1948) pp. 252-53. 
experts.

Railroad leaders very early understood the importance of having persuasive men at the capitol. In 1862, the C.B. \& Q. was apparently not well organized, for the company sent its superintendent to Des Moines. Denison commented from Boston: "I cannot reasonably expect a stranger who is not a talkative man to do much.":37 It was soon discovered that politicians made excellent lobbyists. Fitz Henry Warren and Joshua Tracy of Burlington represented the Burlington road; William W. Hamilton and John F. Duncombe of Dubuque watched over Dubuque interests; John A. Kasson of Des Moines spoke at different times for the Cedar Rapids and Davenport interests. All these men were active in state politics; all held office in the legislature at one time or another. When really important issues arose, the call for the company's top men went to headquarters. Joy and Forbes of the C.B. and Q., Blair of the Cedar Rapids road and Henry Farnam of the C.R.I. \& P. were the men called during the consideration of key issues. They did not always come, but when trouble arose, the call went out. ${ }^{38}$

The most enduring successful technique used by the railroaders played the have-nots against the haves. By convincing legislators representing western districts that the frontier areas would never be reached by railroads if the legislature passed the wrong sort of laws, the railroad lobby utilized a natural source of pro-railroad strength. In 1860, Reid was aware of the probable influence of members who represented the trackless western counties, ${ }^{39}$ but it was 1864 before a positive suggestion to take advantage of these friends appeared. Denison questioned Perkins in 1864; "Is there not some influential man in the country where there is no railroad to take the leadership in opposition to the [tax] law?"40 In 1868, Perkins advised Joshua Tracy to "let the western members understand that the development of the State depends for the present on outside

${ }^{37}$ Denison to Warren, February 28, 1862, CBQ, 5 D4.1.

${ }^{38}$ Perkins to John M. Forbes, June 1, 1864, CO, LPB "C"; Denison to James F. Joy, January 27, 1866, CBQ, 5 D4.1; Reid to D. W. Kilbourne, January $24,1868, D W K$, Vol. 16; J. P. Farley to Jesup, March $5,1868, I C, 8$ D 8.15 .

${ }^{39}$ Reid to D. W. Kilbourne, February 7, 1860, DWK, Vol. 7.

${ }^{40}$ Denison to Perkins, February 13, 1864, $C B Q, 5$ D4.1. 
Capital-Let them understand that to induce such assistance they must Legislate fairly not to say favorably."41

Going beyond influencing present members, Perkins and Platt Smith both recommended entering into the selection of the men who would go to the legislature. "It is necessary . . . to begin now [June, 1865] and see that the proper parties are nominated from the different counties as members of the legislative assembly." ${ }^{42}$ Perkins wrote to several prominent Iowans he knew, inquiring about the 1868 elections. To G. W. Beymer, he wrote, "Do you elect anyone this Coming Fall to the Legislature next winter-Who is likely to go? Would you accept the nomination?":3 This approach was of relatively late fruition and there is little evidence to indicate any systematic influence upon elections.

The widespread distribution of free railroad passes was an approach which also developed relatively late, but which was apparently in full operation by the end of the period under study. Although the House formally expressed thanks to the M. \& M. and the C.\&R. I. in 1857 for "furnishing the members of this House with free tickets over their prospective roads" such generosity was not acknowledged again by the legislature until 1868. ${ }^{44}$ Rather, on specific occasions, the railroads provided free transportation to a specific place, as in the summer of 1856 when Farnam invited the legislators to visit Chicago, or when Kilbourne invited them to visit Keokuk over the completed portion of his railroad in $1862 .{ }^{45}$

A commoner method of distributing passes in the earlier period was on an individual basis. William W. Hamilton, lobbyist for the Dubuque road, received thirty passes for distribution in 1862, with the injunction to keep close records of those who received them. ${ }^{46}$ In 1864, Perkins sent a few passes to Warren with the request that the Senator use them "with

${ }^{4}$ Perkins to Tracy, February 6, 1866, CO, LPB "E".

${ }^{42}$ Smith to John I. Blair, June 9, 1865, as cited in Thomas C. Cochran, Railroad Leaders, 1845-1890 (Cambridge, 1953), p. 463.

${ }^{43}$ Perkins to Beymer, June 22, 1868, CO, LPB "F."

${ }^{44}$ Iowa, House of Representatives Journal, 1856, p. 249.

${ }^{45} I$ bid, 1856, Special Session, Pp. 20, 28; Iowa, Senate Journal, 1862 , p. 560 .

${ }^{46}$ James McKinlay to Hamilton, February 27, 1862, IC, 8 D8.16. 
profit to yourself or to the R. R. Co. I may not approve of such means of gaining friends, but unfortunately, the world is wicked."

By 1868, the wholesale distribution of passes was more common, for the Senate formally thanked the "managers of the several railroads in the State for free passes over their roads." 48 By that year, Kilbourne complained that "this pass business needs some restrictions." He spoke approvingly of a Rock Island policy which restricted legislative passes to three months or to the term of the legislature plus thirty days, indicating that his passes were of longer duration..$^{49}$ A petition in 1870 complained of "yearly passes" and asked for restrictive legislation. ${ }^{50}$ In 1871, the Governor's office sent out complete lists of all the legislators who would attend the coming session to the managers of all the railroads, apparently for pass reasons. ${ }^{51}$ In 1872, the legislature entertained the first bill to prohibit "legislative and judicial officers" from accepting passes, but the bill was, as the leading newspaper in Des Moines phrased it, "choked to death" by a committee.

The railroads were often accused of bribery, but generally with little or no evidence. There were, however, a few instances in which the railroaders discussed or advocated the practice. In 1864, the D.M.V. made an offer of a post-season position as right-of-way agent to the chairman of the Senate railroad committee. This drew the cynical approval of one member of the company, with the added comment, "he can earn his salary, I presume."5:3 During 1868, J. P. Farley was concerned about a vital land grant question. "Nothing can be accomplished without money," he observed. Later, he decided to make a "desperate effort and take the chance of the

${ }^{47}$ Perkins to Warren, January 8, 1864, CO, LPB “D."

${ }^{48}$ Senate Journal, 1868, p. 579 .

${ }^{49} \mathrm{D}$. W. Kilbourne to Reid, January 16, 1868, DWK, LPB

${ }^{50}$ Secretary of State Papers, S IX, Box 539 (State Department of History and Archives, Des Moines). for example.

${ }^{51} \mathrm{~J}$. Loundsberry to S. S. Merrill, November 4, 1871, G II, Vol. II,

${ }^{52}$ House Journal, 1872, pp. 238, 263, 465; Des Moines Daily Iowa State Register, March 19, 1872 .

${ }^{3}$ Leighton to D. W. Kilbourne, February 2, 1864, D. W. Kilbourne to Leighton, February 6, 1864, E. Kilbourne to D. W. Kilbourne, February 8, 1864, DWK, Vol. 10. 
aproval [sic] of our Board of Directors." He said he had to change the votes of seven Representatives and six Senators to achieve his purpose. He was convinced that "the object to be gained will Justify any Laudible Means Necessary [sic] to be used." ${ }^{4}$ Whether money changed hands was not discovered, we do know that his plans failed and the land grant was lost. In 1870, Hugh Reid complained of the high cost of influence and asked for $\$ 10,000$ as operating capital. "I have never seen such a legislature in Iowa where the lawyers are so hungry for fees to pay for working with other members, they themselves being disposed to vote right; but want fees as lawyers for extra work."

In no instance was there a record of the actual expenditure of money to purchase votes, only the discussion of the possibility. Many of the railroaders probably felt like the C.B. \& Q.'s Perkins, who refused to buy up members who were "spoiling for that sort of thing," on the grounds that it would do no good; in fact, it "would be about as profitable as reasoning with a Highwayman." "56 Generally, the purchase of legislation was not necessary. The strength of those opposed to regulatory legislation was usually sufficient to defeat most obnoxious measures or to compromise others.

Railroads sometimes assumed that it was impossible to talk perverse or disgruntled legislators out of their convictions, and that to try would only compound the difficulties. In such cases, silence was the best course. Perkins once counseled against bringing pressure. "I fear that a gathering of $\mathrm{R}$. R. men at Des Moines would turn some honest members against us, who, by judicious behavior on the part of our friendly members, may be brought to us."57 Sometimes, particularly in land grant matters, the railroad men felt as Peter Dey of the M. \& M. did when he wrote, "If possible, I think it policy [sic] for us to avoid legislation," rather than risk an attempt at some positive act. ${ }^{58}$

${ }^{54}$ Farley to Jesup, January 9, 1868, IC, 8 D8.15.

${ }^{55}$ Reid to Leighton, February 6, 1870, DWK, Vol. 19.

"Perkins to H. Strong, January $31,1868, C O, \mathrm{LPB}$ "F." LPB “D.”

"Perkins to Governor Cyrus Carpenter, January 29, 1866, CO,

${ }^{58}$ Dey to Dodge, February 13, 1860, GMD, Vol. 150. 
The railroad men viewed the legislature, at least in its ability to do them harm, with a healthy respect. This appeared frequently in their expressions of fearful anticipation before legislative meetings and of grateful relief when sessions ended. At virtually every session, the correspondence revealed comments such as these:

I also notice that a movement has been made by a member of the House to fix R R tariffs. I do not think it will be safe for you to be away from Des Moines. You cant [sic] tell what they may do. ${ }^{50}$

I am happy to hear that there is a prospect that the Legislature will adjourn without doing anything on the subject of Rail Roads. ${ }^{60}$

Some one of us ought to be on the watch at Des Moines until the close of the Session to prevent any prejudicial Legislation -and as you say, every session must be looked after by R.R. men. ${ }^{61}$

But the actions of Legislatures, like the decisions of courts are very uncertain. ${ }^{62}$

Thank the Lord the session of the Legislature is rapidly drawing to a close and the sooner that event happens the better for the people. ${ }^{\text {63 }}$

What a blessing it would be to the State if the Legislature could only meet once in ten years! ${ }^{64}$

One railroader was so disgusted with the course of the Legislature that he went so far as to suggest that railroads "be put under the control \& protection of the general government. State legislation is too narrow minded to live under."

As soon as the builders had laid the first miles of track in eastern Iowa, their concem about the legislature's actions grew. They insisted that the railroad be represented at every session of the assembly and frequently called for additional help in times of stress. By appealing to sections of the state that were without railroads and to individuals friendly to the railroads, the lobbyists were often able to escape harmful legislation or at least to blunt its effects. Nevertheless, in spite of all their techniques of persuasion, the railroad men were unable to halt a growing belief that railroads must be closely

${ }^{59} \mathrm{D}$. W. Kilbourne to Reid, January $31,1868, D W K$, LPB.

${ }^{60}$ Farnham to Dodge, March 19, 1860, GMD, Vol. 1.

${ }^{61}$ Leighton to D. W. Kilbourne, February 18, 1864, DWK, Vol. 10.

${ }^{62} \mathrm{D}$. W. Kilbourne to Leighton, February 29, 1864, DWK, Vol. 10.

${ }^{63} \mathrm{C}$. H. Perry to Leighton, March 23, 1870, DWK, Vol. 19.

${ }^{64}$ Perkins to Wilson, March $19,1864, C O, \mathrm{LPB}$ "C."

${ }^{65}$ Denison to Joy, March 30, 1866, CBQ, 5 D4.1. 
regulated. The general public, despite efforts to assuage them, increasingly feared the influence of railroads in government. The fact remains, however, that the legislature was by no means the creature of the railroads during this period. Railroad management regarded the state legislature as an unpredictable and certainly an independent body. It can not be denied that the railroaders experienced a great deal of anguish as they tried to gain a measure of legislative support for their young enterprise.

by John Phipps, Museum Director

Two recent additions to the coin display at the Iowa State Historical Museum. should be of interest to almost everyone-the numismatic hobbyist as well as the ordinary citizen.

Both coins came to us without fanfare in a collection of items from a donor in New Hampton, Iowa. The date "1787" and thirteen interlocking circles drew attention to one of the coins, identifying it as a "Fugio" penny-the first coin minted under authorization of the then infant United States. Said to have been designed in part by Benjamin Franklin, it has the motto "Mind Your Business" stamped on its reverse side. These coins were minted by a private firm by the order of Congress and are made of salvaged copper from the bands of powder kegs imported from France during the war for independence.

The second coin is dated " 1866 " and is obviously a "nickle" -in fact it is one of the first coins of five-cent denomination that was minted. Prior to 1866 the silver "half dime" was used -thus the new coin was dubbed the "nickle" to distinguish it from the old "half dime."

Neither coin is particularly rare or of great monetary value, but each is unique, and a welcome addition to the coin collection in the Manuscript Room, first floor west. 
Copyright of Annals of Iowa is the property of State of Iowa, by \& through the State Historical Society of Iowa and its content may not be copied or emailed to multiple sites or posted to a listserv without the copyright holder's express written permission. However, users may print, download, or email articles for individual use. 